\title{
Nexus between financial innovation and economic growth in South Asia: evidence from ARDL and nonlinear ARDL approaches

\author{
Md. Qamruzzaman ${ }^{1,2^{*}}$ (D) and Wei Jianguo ${ }^{2}$
}

\author{
* Correspondence: \\ zaman_wut16@yahoo.com \\ ${ }^{1}$ School of economics, Wuhan \\ University of Technology, Wuhan, \\ China \\ ${ }^{2}$ School of Business and Economics, \\ United International University, \\ Dhaka, Bangladesh
}

\begin{abstract}
This study examined the relationship between financial innovation and economic growth in Bangladesh, India, Pakistan, and Sri Lanka for the period Q1 1975 to Q4 2016. The autoregressive distributed lag (ARDL) bounds test was used to gauge long-run relationships, and the nonlinear ARDL (NARDL) test was used to explore asymmetry between financial innovation and economic growth in the sample of Asian countries. The findings from the bounds tests revealed long-run cointegration between financial innovation and economic growth in the sample countries. Furthermore, NARDL confirmed that positive changes in financial innovation linked positively with economic growth and vice versa in the long run. In the short run, however, the study found mixed behaviors in the case of positive and negative changes in financial innovation. To investigate directional causality, the Granger causality test under an error correction model was employed. The Granger causality results supported the feedback hypothesis in both the long run and short run. Thus, financial innovation boosts economic growth in the long run by stimulating financial service expansion, financial efficiency, capital accumulation, and efficient financial intermediation, which are essential for sustainable economic growth.
\end{abstract}

Keywords: Financial innovation, Economic growth, ARDL, NARDL, JEL, O52, C21

\section{Introduction}

In Schumpeter's development theory, finance and efficient financial institutions are crucial for sustainable economic growth, assuming that credit, money, and finance influence innovation processes (Knell 2015). Following Schumpeter's (1911) seminal work, other finance scholars-including, Goldsmith (1969), Greenwood and Jovanovic (1990), Gurley and Shaw (1955), and Patrick (1966) - advocated for financial efficiency to ensure the smooth flow of capital across countries, playing an intermediation role that is a critical determinant of economic growth. An efficient financial system is the outcome of financial institutional development in capital markets and the diversification of financial instruments (Ndlovu 2013). An efficient financial system can achieve, through the adoption and diffusion of technological improvements, new financial institutions, new financial intermediation, and efficiency in financial services (Wachter 2006; Saqib 2015). The nexus between financial sector development and economic growth has been well tested and documented in a large number of empirical studies

(c) The Author(s). 2018 Open Access This article is distributed under the terms of the Creative Commons Attribution 4.0 International License (http://creativecommons.org/licenses/by/4.0/), which permits unrestricted use, distribution, and reproduction in any medium, provided you give appropriate credit to the original author(s) and the source, provide a link to the Creative Commons license, and indicate if changes were made. 
(e.g., Patrick 1966; Jung 1986; Gregorio and Guidotti 1995; Levine 1997; Rahman 2004; Khan et al. 2005; Ilhan 2008; Wadud 2009).

Finance researchers-including Arestis and Demetriades (1997), Demetriades and Luintel (1996), and King and Levine (1993b) - have suggested that the financial sector contributes to the economic growth of developed countries, greatly influencing the pursuit of continuous financial innovation in the financial system. Moreover, financial innovation provides opportunities for growth in the financial sector (Napier 2014), thus boosting economic growth. Financial innovation also allows for the expansion of financial services through the development of new financial institutions, financial instruments, financial reporting, technology, and market knowledge (Michalopoulos et al. 2009). According to Merton (1992) and Tufano (2003), financial innovation responds to problems and opportunities in the market as well as asymmetric information.

Over the past decade, many empirical studies have confirmed a positive association between financial innovation and economic growth (e.g., Lumpkin 2010; Sekhar 2013). Financial innovation helps economic growth by allowing for capital mobilization, efficient financial intermediation, capital accumulation, and enhanced overall efficiency in financial institutions. That is why financial innovation is treated as a prime catalyst for financial development (Laeven et al. 2015). As with other innovations, financial innovation is a continuous process of bringing about changes in the financial system through the improvement and diversification of financial products and processes (Sood and Ranjan 2015). Demetriades and Andrianova (2005) argued that emergence of new financial assets and services in the financial system improves banking-sector performance and capital-market development, eventually boosting economic growth in the host country. Schumpeter (1912, 1982), meanwhile, argued that robust financial systems comprise efficient financial institutions, diversified financial assets and services, comprehensive financial services coverage, efficient channels for economic resource mobilization, and available credit flows for investment across a country. Financial innovation made credit available in economies by way of new and hybrid forms of financial institutions (e.g., microfinance institutions) outside the framework of formal banking systems (Blair 2011).

Thus far, the existing empirical literature has highlighted a definite nexus between financial innovation and economic growth, and the effect of financial innovation is especially evident in developing countries. The present study is unique in that it aimed to investigate both symmetric and asymmetric relationships by applying newly developed autoregressive distributed lag (ARDL) bounds testing (Pesaran et al. 2001) and nonlinear ARDL (NARDL) (Shin et al. 2014) to cover a wide range of time series data, from Q1 1975 to Q4 2016. To our knowledge, this is the first research to investigate financial innovation's effect on economic growth in South Asian countries.

The rest of this paper proceeds as follows. Section "Literature review" provides a literature review concerning the nexus between financial innovation and economic growth. Section "Methods" presents the research data and the research model, as well as the econometric methodology used for analysis. Section "Data analysis and interpretation" concerns model estimation along with in-depth interpretation and discussion. Section "Conclusions and recommendations" concludes the paper and discusses the scope for further research. 


\section{Literature review}

Financial sector development generates economic growth because an efficient financial sector mobilizes economic resources in an economy (Ndlovu 2013). Moreover, an efficient financial system drives the processes of creating wealth, trade, and, most importantly, capital formation (Ahmed 2006). Innovation in financial institutions enhances the level of efficiency, and efficient financial systems act as catalysts for economic development through financial development (Saad 2014; Michael et al. 2015).

In modern economies, innovation plays a key role in transforming a static economy into a dynamic one with the adoption and diffusion of technological advancement, new organizational structures, production processes, and management styles. Today, innovation not only involves the creation of new things but also provides solutions to ongoing problems in an economy (Kotsemir and Abroskin 2013).

Considering Schumpeterian endogenous growth theory, many empirical studies have shown that financial services promote economic growth (e.g., Aghion and Howitt 1990; Howitt 2000; Dosi et al. 2010; Phillips et al. 1999). King and Levine (1993a) argued that financial services expand financial activities, increase the rate of capital accumulation, and boost financial development; the introduction of new financial services in a financial system is the key output of financial innovation. The literature has also argued for financial innovation's role in financial development by way of improving financial efficiency in financial systems. Financial innovation assists financial development through the expansion of financial services by offering new financial products, optimizing economic resource mobilization through efficient payment mechanisms, reducing investment risks, and accelerating capital formation. Therefore, financial innovation is regarded as an engine of financial growth in both developed and developing countries (Miller 1986, 1992). Ahmed (2006) argued that financial-sector growth expedites cross-county trade, wealth creation, and capital accumulation in an economy. Ahmad and Malik (2009), meanwhile, argued that financial-sector development reduces asymmetric information costs and enhances resource mobilization, thus boosting economic growth.

Financial innovation is associated with the development of new financial instruments, corporate structures, financial institutions, and accounting and financial reporting techniques (Michalopoulos et al. 2011). Financial innovation is considered the "engine" driving a financial system toward its goal of improving the performance of what economists call the "real economy" (Merton 1992). Michalopoulos et al. (2011) measured financial innovation as the growth of financial development, using the growth rate of the ratio of bank credit to the private sector to the GDP as a proxy for financial innovation. However, since nothing is completely new, financial innovations often involve adaptations or modifications of existing products and processes that ensure efficiency and hence profitability.

Empirical research in finance has proposed four distinct hypotheses to explain the nexus between financial innovation and economic growth. First, the supply-leading hypothesis suggests that financial innovation can positively affect a country's economic growth (Beck 2010). This hypothesis suggests that financial innovation in a financial system accelerates economic growth by expediting the process of capital accumulation, enhancing efficiency in financial institutions, improving financial services, and making financial intermediation more efficient. Shittu (2012) found that efficient financial 
intermediation significantly influenced economic growth in Nigeria. Second, the demand-leading hypothesis suggests that economic growth attracts financial innovation in an economy. This hypothesis suggests that the expansion of economic activities, real sector development, and increased domestic and international trade place pressure on financial systems to improve payment mechanisms, make financial institutions more efficient, and diversify financial assets to reduce investment risks. Third, the feedback hypothesis suggests bidirectional causality between financial innovation and economic growth. Bara and Mudxingiri (2016) and Bara et al. (2016), for example, confirmed bidirectional causality between financial innovation and economic growth. Lumpkin (2010) and Sekhar (2013), however, found no causality between financial innovation and economic growth.

Given both the positive and negative effects of financial innovation, many studies have explored the positive association between financial innovation and economic growth in a host country. Sood and Ranjan (2015), for example, studied India while Qamruzzaman and Jianguo (2017) studied Bangladesh. Despite the positive associations, negative aspects have also been found in the nexus between financial innovation and economic growth. Adu-Asare Idun and Aboagye (2014) used ARDL to explore the negative association between financial innovation and economic growth in Ghana. They argued that innovative financial products negatively influenced saving propensity in Ghana, encouraging the withdrawal of savings from banks and thus creating a problem of bank liquidity. Similarly, Ansong et al. (2011) argued that excessive financial innovation adversely affected banks with diversified financial products.

Financial innovation expedites the overall performance of financial systems through the emergence of new financial institutions, financial instruments, and new channels for providing services to an economy (Bourne and Attzs 2010).

\section{Methods}

Data

This study used quarterly time series data for the period Q1 1975 to Q4 2016. Data were collected from publicly available sources, including the World Development Indicators published by the World Bank (2017), the World Economic Outlook (2017) published by the IMF, the Bangladesh Economic Review published by the Ministry of Finance (2016), and the South Asian Economy published by the Asian Development Bank (2017). The econometric analysis package EViews 9.5 (2017) was used for data analysis.

We considered the growth rate of gross domestic product (GDP) per capital as a proxy for economic growth $(\mathrm{Y})$, along with one independent variable as a proxy for financial innovation.

Financial innovation is a continuous process associated with the emergence of new financial institutions, new financial assets, improved financial services, and improved payment mechanisms (Sood and Ranjan 2015). It is not possible to gauge the effect of financial innovation on economic growth by considering only a single indicator; there is no agreed-upon proxy in the literature. Hence, researchers have used various proxies. Laeven et al. (2015) argued that financial innovation involves not only the emergence of new financial instruments and products but also developments in the financial 
system via new financial reporting processes, improved credit rationing, and advancements in data processing. Therefore, the selection of proxies for financial innovation should cover wide-ranging aspects of the financial system.

Research in the past decade has used bank credit to the private sector as a proxy indicator for financial innovation (e.g., Adu-Asare Idun and Aboagye 2014; Michalopoulos et al. 2009). However, many empirical studies have used the ratio of broad-to-narrow money as a proxy for financial innovation (e.g., Bara and Mudxingiri 2016; Bara et al. 2016; Qamruzzaman and Jianguo 2017; Ansong et al. 2011; Mannah-Blankson and Belnye 2004). This study followed the same path for investigation.

We also used a set of macroeconomic variables as control variables to bring about robustness in estimation. These included trade openness (TO), gross capital formation (GCF), and domestic credit to private sector (DCP).

Trade openness (TO) indicates the extent to which an economy relies on international trade. It is calculated considering both imports and exports in relation to GDP. A higher ratio implies a profound reliance on international trade. TO positively influences the production level of an economy by creating opportunities to serve foreign over domestic markets. TO also helps increase productivity through technological advancement, knowledge sharing, and increased labor productivity.

Gross capital formation (GCF) is a key factor in economic growth. Solow (1957) argued that physical capital accumulation increases productivity in an economy. GCF refers to the net addition of physical capital or assets after deducting disposal. Empirical studies such as Ghali and Ahmed (1999), Levine and Renelt (1992), and Barro (1991) have confirmed positive associations between GCF and economic growth.

Domestic credit to private sector (DCP) signifies capital flow to the private sector from financial institutions in the form of loans, trade credits, and nonequity investments. Studies such as Were et al. (2012), Beck and Levine (2004), and Ang (2008) found positive contributions to economic growth via DCP. All of the variables were converted into natural logarithms to ensure accuracy and robustness in the estimations (Shahbaz et al. 2016). Table 1 summarizes the descriptive statistics of the research variables.

\section{Autoregressive distributed lag (ARDL)}

Based on our research variables, the generalized form of our study model can be represented as follows:

$$
\overbrace{Y}^{\text {Economic Growth }}=\overbrace{F I}^{\text {Financial Innovation }}, \overbrace{T O, G C F, D C P}^{\text {Macroeconomic Variables }}
$$

After transforming Eq. (1) into a linear form, it can be represented as follows:

$$
\ln Y_{t}=\alpha_{0}+\beta_{1} \ln F I_{t}++\beta_{2} \ln T O_{t}+\beta_{3} \ln G C F_{t}+\beta_{4} \ln D C P_{t}+\epsilon_{t},
$$

where $\mathrm{Y}$ is economic growth, FI is financial innovation, GCF is gross capital formation, TO is trade openness, and DCP is domestic credit to private sector. The model coefficients of $\beta 1$ to $\beta 4$ represent long-run elasticity, and $\epsilon t$ is the error correction term. However, Eq. (2) can only represent the long-run impact on economic growth from an 
Table 1 Summary of descriptive statistics of research variables

\begin{tabular}{|c|c|c|c|c|c|c|c|c|c|c|c|}
\hline & \multicolumn{5}{|c|}{ Descriptive statistics } & \multicolumn{6}{|c|}{ Correlation Matrix } \\
\hline & $\ln Y$ & $\ln F \mid$ & $\operatorname{lnTO}$ & $\operatorname{lnGCF}$ & $\operatorname{lnDCP}$ & & $\ln Y$ & $\ln F \mid$ & $\operatorname{lnTO}$ & $\operatorname{lnGCF}$ & $\ln D C P$ \\
\hline \multicolumn{12}{|c|}{ Country: Bangladesh } \\
\hline Mean & 0.827 & 3.322 & 3.24 & 2.215 & 2.757 & $\ln Y$ & 1 & & & & \\
\hline Median & 1.108 & 3.26 & 3.206 & 2.18 & 2.864 & $\operatorname{lnFl}$ & 0.395 & 1 & & & \\
\hline Maximum & 2.046 & 4.166 & 3.873 & 4.992 & 3.782 & $\operatorname{lnTO}$ & 0.444 & 0.284 & 1 & & \\
\hline Minimum & -3.177 & 2.122 & 2.397 & 0.426 & 0.65 & $\operatorname{lnGCF}$ & 0.261 & -0.349 & -0.175 & 1 & \\
\hline Std. Dev. & 1.019 & 0.557 & 0.364 & 0.708 & 0.816 & $\operatorname{lnDCP}$ & 0.265 & 0.454 & 0.216 & -0.031 & 1 \\
\hline Skewness & -1.972 & -0.062 & 0.088 & 1.113 & -0.83 & & & & & & \\
\hline Kurtosis & 7.494 & 1.966 & 2.278 & 7.74 & 2.978 & & & & & & \\
\hline Observations & 42 & 42 & 42 & 42 & 42 & & & & & & \\
\hline \multicolumn{12}{|l|}{ Country: India } \\
\hline Mean & 1.314 & 3.821 & 3.046 & 2.031 & 3.282 & $\ln Y$ & 1 & & & & \\
\hline Median & 1.455 & 3.763 & 2.928 & 2.322 & 3.186 & $\ln F \mid$ & 0.372 & 1 & & & \\
\hline Maximum & 2.169 & 4.367 & 4.02 & 3.457 & 3.948 & InTO & 0.317 & 0.235 & 1 & & \\
\hline Minimum & -0.429 & 3.11 & 2.366 & -2.948 & 2.54 & $\operatorname{lnGCF}$ & 0.264 & 0.176 & 0.283 & 1 & \\
\hline Std. Dev. & 0.652 & 0.337 & 0.52 & 1.143 & 0.354 & $\operatorname{lnDCP}$ & 0.463 & 0.162 & 0.311 & 0.123 & 1 \\
\hline Skewness & -0.926 & 0.003 & 0.584 & -2.512 & 0.475 & & & & & & \\
\hline Kurtosis & 3.083 & 2.311 & 1.942 & 10.919 & 2.668 & & & & & & \\
\hline Observations & 42 & 42 & 42 & 42 & 42 & & & & & & \\
\hline \multicolumn{12}{|l|}{ Country: Pakistan } \\
\hline Mean & 0.503 & 3.79 & 3.515 & 1.519 & 3.16 & $\ln Y$ & 1 & & & & \\
\hline Median & 0.722 & 3.774 & 3.517 & 1.576 & 3.186 & $\operatorname{lnFI}$ & -0.05 & 1 & & & \\
\hline Maximum & 1.9 & 4.075 & 3.661 & 2.919 & 3.394 & InTO & 0.097 & 0.117 & 1 & & \\
\hline Minimum & -2.415 & 3.516 & 3.322 & -1.389 & 2.77 & $\operatorname{lnGCF}$ & 0.168 & -0.066 & 0.076 & 1 & \\
\hline Std. Dev. & 0.935 & 0.127 & 0.083 & 0.803 & 0.149 & $\operatorname{lnDCP}$ & 0.203 & 0.049 & 0.271 & 0.144 & 1 \\
\hline Skewness & -0.959 & 0.232 & -0.456 & -1.191 & -0.961 & & & & & & \\
\hline Kurtosis & 3.931 & 2.467 & 2.865 & 6.04 & 3.748 & & & & & & \\
\hline Observations & 42 & 42 & 42 & 42 & 42 & & & & & & \\
\hline \multicolumn{12}{|l|}{ Country: Sr Lanka } \\
\hline Mean & 1.232 & 3.505 & 4.218 & 2.109 & 3.103 & $\ln Y$ & 1 & & & & \\
\hline Median & 1.353 & 3.484 & 4.228 & 2.178 & 3.119 & $\ln F \mid$ & 0.272 & 1 & & & \\
\hline Maximum & 2.118 & 3.85 & 4.484 & 4.411 & 3.571 & InTO & 0.133 & 0.062 & 1 & & \\
\hline Minimum & -2.026 & 2.887 & 3.836 & -0.691 & 2.177 & $\operatorname{lnGCF}$ & 0.351 & -0.197 & -0.016 & 1 & \\
\hline Std. Dev. & 0.714 & 0.215 & 0.166 & 1.019 & 0.402 & $\operatorname{lnDCP}$ & 0.214 & 0.751 & -0.083 & -0.054 & 1 \\
\hline Skewness & -2.619 & -0.975 & -0.619 & -0.457 & -0.799 & & & & & & \\
\hline Kurtosis & 12.058 & 3.955 & 2.555 & 3.584 & 2.686 & & & & & & \\
\hline Observations & 42 & 42 & 42 & 42 & 42 & & & & & & \\
\hline
\end{tabular}

explanatory variable. To gauge long-run cointergration and short-run elasticities in the model, we used a cointergration test.

Various cointegration tests have been used in recent decades, including Engle and Granger (1987), based on residuals, and Johansen (1998, 1991, 1995) and Johansen and Juselius (1990), based on maximum likelihood tests. Earlier models had limitations with regard to the order of integration of variables. To address this issue, Pesaran and Shin 
(1998) proposed a new cointegration model with greater flexibility in the variable integration order-namely, $\mathrm{I}(0)$ and/or I(1). This was further extended by Pesaran et al. (2001) and Narayan (2004). Moreover, the error correction term can be derived from ARDL through linear transformation. Thus, Eq. (2) can be rewritten in ARDL form as follows:

$$
\begin{aligned}
\Delta \ln Y_{t}=\alpha_{0} & +\sum_{i=1}^{n} \mu_{1} \Delta \ln Y_{t-i}+\sum_{i=0}^{n} \mu_{2} \Delta \ln F I_{t-i}+\sum_{i=0}^{n} \mu_{3} \Delta \ln T O_{t-i}+\sum_{i=0}^{n} \mu_{4} \Delta \ln G C F_{t} \\
& +\sum_{i=0}^{n} \mu_{5} \Delta \ln D C P_{t}+\gamma_{0} \ln Y_{t-1}+\gamma_{1} \ln F I_{t-1}+\gamma_{2} \ln T O_{t-1}+\gamma_{3} \ln G C F_{t-1} \\
& +\gamma_{4} \ln D C P_{t-1}+\omega_{t}
\end{aligned}
$$

Further, Eq. (3) can be rewritten into matrix form where each study variable serves as the dependent variable in the model (see Eq. (4)). To gauge the existence of long-run and short-run cointegration, we formulated hypotheses in both cases. For the long run, the null hypothesis $(H 0)$ is no cointergration existence $[H 0: \gamma 11$ to $\gamma 55=0]$. The alternative hypothesis $(H 1)$ is the existence of cointergration $[H 0: \gamma 11$ to $\gamma 55 \neq 0]$. For short-run, the null hypothesis $(H 0)$ is no short-run relationship $[H 0: \mu 11$ to $\mu 55=0]$, and in the alternative hypothesis $(H 1)$, there is a short-run relation $[H 0: \mu 11$ to $\mu 55 \neq 0]$ :

$$
\begin{aligned}
& (1-B)\left[\begin{array}{c}
\ln Y \\
\ln F I \\
\ln T O \\
\ln G C F \\
\ln D C P
\end{array}\right]=\left[\begin{array}{c}
\alpha_{01} \\
\alpha_{02} \\
\alpha_{03} \\
\alpha_{04} \\
\alpha_{04}
\end{array}\right]+\sum_{i=1}^{k} 1-B\left[\begin{array}{c}
\ln Y \\
\ln F I \\
\ln T O \\
\ln G C F \\
\ln D C P
\end{array}\right]_{t-i} \times\left[\begin{array}{lllll}
\mu_{11} & \mu_{12} & \mu_{13} & \mu_{14} & \mu_{15} \\
\mu_{21} & \mu_{22} & \mu_{23} & \mu_{24} & \mu_{25} \\
\mu_{31} & \mu_{32} & \mu_{33} & \mu_{34} & \mu_{35} \\
\mu_{41} & \mu_{42} & \mu_{43} & \mu_{44} & \mu_{45} \\
\mu_{51} & \mu_{52} & \mu_{53} & \mu_{54} & \mu_{55}
\end{array}\right] \\
& +\left[\begin{array}{c}
\ln Y \\
\ln F I \\
\ln T O \\
\ln G C F \\
\ln D C P
\end{array}\right]_{t-1} \times\left[\begin{array}{lllll}
\gamma_{11} & \gamma_{12} & \gamma_{13} & \gamma_{14} & \gamma_{15} \\
\gamma_{21} & \gamma_{22} & \gamma_{23} & \gamma_{24} & \gamma_{25} \\
\gamma_{31} & \gamma_{32} & \gamma_{33} & \gamma_{34} & \gamma_{35} \\
\gamma_{41} & \gamma_{42} & \gamma_{43} & \gamma_{44} & \gamma_{45} \\
\gamma_{51} & \gamma_{52} & \gamma_{53} & \gamma_{54} & \gamma_{55}
\end{array}\right]+\left[\begin{array}{c}
\omega \\
\omega \\
\omega \\
\omega \\
\omega
\end{array}\right]_{t}
\end{aligned}
$$

where $\Delta$ is the first difference operator, and the coefficients $\mu 1$ to $\mu 5$ and $\gamma 0$ to $\gamma 4$ represent short-run and long-run elasticities, respectively. In addition, $\alpha 0$ is the constant term, and $\omega t$ represents white noise.

Acceptance or rejection of the hypothesis is based on a comparison between the f-statistic and the critical value. We used the critical value proposed by Pesaran et al. (2001), Narayan (2004), and Narayan and Narayan (2005) to make a conclusive statement about cointegration. If the f-statistic was higher than the upper bound of the critical value, it indicated the existence of long-run associations among the variables.

\section{Nonlinear ARDL approach}

Estimating long-run association by applying the cointegration test is based on the symmetric assumption that the explanatory variable linearly influences the dependent variable. In reality, movements in a variable can change in either direction, positive or 
negative. Considering positive and negative changes in an independent variable, we tried to investigate the asymmetric relationship between variables by applying the recently developed nonlinear ARDL approach proposed by Shin et al. (2014).

In the process of formulating nonlinear ARDL by considering the previous ARDL Eq. (4), we decomposed the independent variable into two additional sets of series based on positive and negative changes, following Delatte and López-Villavicencio (2012), Verheyen (2013), Bahmani-Oskooee and Mohammadian (2016), and Bahmani-Oskooee et al. (2005). We decomposed positive and negative changes for financial innovation (FI) denoted by FI+ and FI- as follows:

$$
\left\{\begin{array}{l}
\operatorname{POS}(F I)_{t}=\sum_{L=1}^{t} \ln F I_{L}^{+}=\sum_{L=1}^{T} \operatorname{MAX}\left(\Delta \ln F I_{L}, 0\right) \\
N E G(F I)_{t}=\sum_{L=1}^{t} \ln F I_{k}^{-}=\sum_{L=1}^{T} \operatorname{MIN}\left(\Delta \ln F I_{L}, 0\right)
\end{array}\right.
$$

Now, we can rewrite Eq. (3) in nonlinear form by incorporating a new series of positive and negative changes. The nonlinear ARDL is as follows:

$$
\begin{aligned}
\Delta \ln Y_{t}=\alpha_{0} & +\sum_{i=1}^{n} \mu_{1} \Delta \ln Y_{t-i}+\sum_{i=0}^{n} \mu_{2}^{+} \Delta \ln P O S(F I)_{t-i}+\sum_{i=0}^{n} \mu_{2}^{-} \Delta \ln N E G(F I)_{t-i} \\
& +\sum_{i=0}^{n} \mu_{3} \Delta \ln T O_{t-i}+\sum_{i=0}^{n} \mu_{4} \Delta \ln G C F_{t}+\sum_{i=0}^{n} \mu_{5} \Delta \ln D C P_{t}+\gamma_{0} \ln Y_{t-1} \\
& +\gamma_{1}^{+} \ln P O S(F I)_{t-1}+\gamma_{1}^{-} \ln N E G(F I)_{t-1}+\gamma_{2} \ln T O_{t-1}+\gamma_{3} \ln G C F_{t-1} \\
& +\gamma_{4} \ln D C P_{t-1}+\omega_{t}
\end{aligned}
$$

In Eq. (6), the coefficients of $\mu 1$ to $\mu 5$ denote short-run elasticities, and the coefficients of $\gamma 0$ to $\gamma 4$ denote long-run elasticities in the model. To gauge both long-run and short-run asymmetric tests, we ran the Wald test. $Y t$ represents economic growth, It represents financial innovation, TOt represents trade openness, GCFt represents gross capital formation, and DCFt represents domestic credit to private sector. Further, $\mathrm{n}$ represents optimal lag, which was determined using the Akaike information criterion (AIC). According to Shin et al. (2014), the confirmation of long-run cointegration using the bounds test approach is also applicable by comparing the f-statistic (Wald test) and the critical value, as proposed by Pesaran et al. (2001). The null hypothesis is $\gamma 0=\gamma 1+=\gamma 1-=0$.

\section{Data analysis and interpretation}

\section{Unit root test}

Investigating cointegration by applying ARDL bounds testing is not influenced by the order of integration of variables. However, empirical studies have suggested that the existence of a second-order integrated I(2) variable can produce spurious estimations in the regression model. Therefore, to ascertain the variable order of integration, we estimated the stationary test by applying the ADF test proposed by Dickey and Fuller (1979), the P-P test proposed by Phillips and Perron (1988), and the KPSS proposed by 
Table 2 Unit root test estimation

\begin{tabular}{|c|c|c|c|c|c|c|c|c|c|}
\hline & \multicolumn{3}{|l|}{ ADF } & \multicolumn{3}{|l|}{ P-P } & \multicolumn{3}{|l|}{ KPSS } \\
\hline & At level & $\Delta$ & 1 & At level & $\Delta$ & I & At level & $\Delta$ & I \\
\hline \multicolumn{10}{|c|}{ Bangladesh } \\
\hline $\ln Y$ & $-3.90^{\mathrm{b}}$ & - & $\mid(0)$ & - & $-2.77^{\mathrm{a}}$ & $\mathrm{I}(0)$ & 0.06 & $0.38^{a}$ & $\mid(1)$ \\
\hline $\operatorname{InFI}$ & -1.26 & $-5.95^{\mathrm{a}}$ & $\mid(1)$ & -1.11 & $-7.52^{\mathrm{a}}$ & $\mathrm{I}(1)$ & $0.19^{b}$ & - & $\mid(0)$ \\
\hline $\operatorname{lnDCP}$ & -1.03 & $-5.15^{\mathrm{a}}$ & $\mathrm{I}(1)$ & -0.89 & $-6.29^{a}$ & $I(1)$ & $0.22^{\mathrm{a}}$ & - & $I(0)$ \\
\hline InTO & -2.25 & $-5.74^{a}$ & $\mid(1)$ & -1.17 & $-7.09^{\mathrm{a}}$ & $\mid(1)$ & $0.17^{b}$ & - & I(0) \\
\hline $\ln G C F$ & -1.25 & $-4.96^{\mathrm{b}}$ & $\mid(1)$ & -2.44 & $-3.86^{\mathrm{b}}$ & $\mathrm{I}(1)$ & 0.11 & $0.21^{b}$ & $\mid(1)$ \\
\hline \multicolumn{10}{|l|}{ India } \\
\hline $\ln Y$ & $-4.96^{\mathrm{b}}$ & - & I(0) & $-4.93^{\mathrm{a}}$ & - & $\mid(0)$ & 0.07 & $0.29^{a}$ & I(1) \\
\hline $\operatorname{InFI}$ & -3.17 & $-4.82^{\mathrm{a}}$ & $\mid(1)$ & -2.50 & $-4.74^{\mathrm{a}}$ & $I(1)$ & 0.08 & $0.39^{a}$ & $\mid(1)$ \\
\hline $\operatorname{lnDCP}$ & $-3.69^{b}$ & - & $\mathrm{I}(0)$ & $-3.69^{b}$ & - & $\mathrm{I}(0)$ & 0.11 & $0.15^{\mathrm{b}}$ & $\mid(1)$ \\
\hline InTO & -3.19 & $-3.66^{\mathrm{b}}$ & $I(1)$ & -3.41 & $-6.37^{\mathrm{a}}$ & $\mid(1)$ & 0.12 & $0.17^{b}$ & $\mid(1)$ \\
\hline $\operatorname{lnGCF}$ & -2.39 & $-3.98^{b}$ & $\mid(1)$ & $-1.98^{c}$ & $-6.60^{a}$ & I(1) & 0.09 & $0.19^{b}$ & I(1) \\
\hline \multicolumn{10}{|l|}{ Pakistan } \\
\hline $\ln Y$ & $-4.75^{b}$ & & $\mathrm{I}(0)$ & $-4.71^{b}$ & & $\mathrm{I}(0)$ & 0.11 & $0.39^{a}$ & $\mid(1)$ \\
\hline $\operatorname{InFI}$ & -1.63 & $-5.6^{a}$ & $\mid(1)$ & -1.57 & $-5.85^{\mathrm{a}}$ & $\mid(1)$ & 0.08 & $0.55^{\mathrm{a}}$ & $I(1)$ \\
\hline $\operatorname{lnDCP}$ & -5.94 & & $\mathrm{I}(0)$ & $-6.01^{a}$ & & $\mathrm{I}(0)$ & 0.18 & $0.28^{\mathrm{a}}$ & $\mid(1)$ \\
\hline InTO & -2.66 & $-7.1^{\mathrm{a}}$ & $\mathrm{I}(1)$ & -2.68 & $-7.46^{\mathrm{a}}$ & $I(1)$ & 0.10 & $0.47^{\mathrm{a}}$ & I(1) \\
\hline $\operatorname{lnGCF}$ & -1.14 & $-5.71^{b}$ & $\mid(1)$ & -1.51 & $-5.72^{\mathrm{a}}$ & $\mathrm{I}(1)$ & 0.09 & $0.42^{\mathrm{a}}$ & $\mid(1)$ \\
\hline \multicolumn{10}{|l|}{ SriLanka } \\
\hline $\ln Y$ & $-4.68^{\mathrm{a}}$ & & I(0) & $-4.66^{a}$ & & $\mid(0)$ & $0.28^{a}$ & & $\mid(0)$ \\
\hline $\operatorname{InFI}$ & -1.17 & $-7.91^{\mathrm{a}}$ & $\mid(1)$ & -1.05 & $-7.76^{\mathrm{a}}$ & $I(1)$ & 0.12 & $0.37^{b}$ & $\mid(1)$ \\
\hline $\operatorname{lnDCP}$ & $-9.52^{\mathrm{a}}$ & & $\mid(0)$ & $-8.94^{\mathrm{a}}$ & & $\mid(0)$ & $0.47^{\mathrm{a}}$ & & $\mid(0)$ \\
\hline InTO & -1.018 & $-5.26^{\mathrm{a}}$ & $\mid(1)$ & -1.28 & $-5.26^{\mathrm{a}}$ & $\mid(1)$ & 0.11 & $0.59^{a}$ & $\mid(1)$ \\
\hline $\ln G C F$ & -1.68 & $-5.98^{b}$ & $\mathrm{I}(1)$ & -1.33 & $-6.16^{\mathrm{a}}$ & $\mathrm{I}(1)$ & 0.14 & $0.48^{b}$ & $\mid(1)$ \\
\hline
\end{tabular}

Note 1. Y for economic growth, FI for financial innovation, DCP for Domestic Credit to Private Sector, TO of Trade Openness, and GCF for Gross Capital Formation

Note 2. All the variables converted into the natural log for estimation

Note 3. ADF for Augmented Dickey-Fuller, P-P for Phillips-Perron, and KPSS for Kwiatkowski-Phillips-Schmidt-Shin

Note $4 .{ }^{\mathrm{a}} \mathrm{b}^{\mathrm{c}}$ indicates significance level as 1,5 , and $10 \%$ respectively

Note 5. "I" for an order of integration, $\Delta$ for first difference operator,

Kwiatkowski et al. (1992). The stationary test estimations are shown in Table 2. The stationary test confirmed the nonexistence of second-order integrated variables, indicating that the order of variable integration was either at the level of $\mathrm{I}(0)$ or after the first difference I(1). Given such variable characteristics, we ran the cointegration test to ascertain long-run associations.

\section{ARDL bounds testing}

\section{Cointegration}

We investigated long-run association by applying the ARDL bounds testing approach proposed by Pesaran et al. (2001) under the symmetric assumption using Eq. (4), where each variable serves as the dependent variable. Table 2 shows the cointegration test results. When economic growth $(\mathrm{Y})$ serves as the dependent variable, the f-statistics $F B D=16.95, I N D=13.40, F P A K=14.66$, and $F S L=8.91$, which are higher than the critical value of the $1 \%$ level of significance. In addition, when the remaining variables 
serve as the dependent variables in the model, the calculated f-statistics are less than the lower bound critical value (3.74). This suggests that the null hypothesis, no cointegration, cannot be accepted; rather, the study confirms the existence of long-run cointegration between FI, TO, GCF, and DCP.

\section{Long-run and short-run estimation for the period Q1 1975 to Q4 2016}

We confirmed long-run cointegration between economic growth and its determinant when economic growth $(\mathrm{Y})$ serves as the dependent variable. Here, we estimate both long-run and short-run elasticities using Eq. (3). Table 3 shows the estimated results.

For the long run (see Table 4, Panel A), all explanatory variables were statistically significant and positively influenced economic growth, which is supported by previous literature. Among all repressors, the magnitude of the effect of financial innovation on economic growth is noteworthy. For instance, we found that a $1 \%$ increase in financial innovation could increase economic growth by $1.22 \%$ in Bangladesh, $1.795 \%$ in India, 1.17\% in Pakistan, and $0.91 \%$ in Sri Lanka. This suggests that the emergence of financial innovation plays a decisive role in economic growth. Silve and Plekhanov (2014) suggested that financial innovation plays an essential role in the efficient mobilization of economic resources, efficient financial intermediation, and the emergence of high-quality financial institutions, thereby accelerating economic growth. Wachter (2006), meanwhile, argued that financial innovation contributes to economies by restructuring and transforming financial systems with innovative institutions and financial services.

The short-run model elasticities are presented in Table 4 (panel B). The coefficient of the error correction term $(E C T t-1)$ represents the speed of adjustment toward long-run equilibrium from any short-run shock in the repressors. The error correction term ECTt - 1 in each model was negative and statistically significant along with higher coefficients. This suggests that disequilibrium can adjust to the long run with higher speed, having any prior-year shock in the explanatory variables. We also found that the impact of financial innovation on economic growth was positively associated, having less significant elasticities.

As in previous empirical studies (e.g., Narayan and Narayan 2005; Qamruzzaman and Jianguo 2017; Paul 2014), we performed a model stability test through four residual diagnostic tests. The test for autocorrelation confirmed the absence of serial

Table 3 ARDL bound testing results

\begin{tabular}{|c|c|c|c|c|c|c|c|c|c|}
\hline \multirow[t]{3}{*}{ Model } & \multicolumn{9}{|c|}{ Country } \\
\hline & \multicolumn{3}{|c|}{ Bangladesh } & \multicolumn{2}{|l|}{ India } & \multicolumn{2}{|c|}{ Pakistan } & \multicolumn{2}{|c|}{ Sri Lanka } \\
\hline & F-stat & Remark & & F-stat & Remark & F-stat & Remark & F-stat & Remark \\
\hline$\overline{F(Y)}=(Y / F I, T O, G C F, D C P$ & 16.95 & Presen & & 13.40 & Present & 14.66 & Present & 8.91 & Present \\
\hline$F(F)=(F I / Y, T O, G C F, D C P)$ & 2.17 & Presen & & 2.85 & Present & 1.15 & Absent & 1.18 & Present \\
\hline$F(T O)=(T O / Y, F l, G C F, D C P)$ & 3.19 & Absent & & 1.65 & Absent & 3.15 & Absent & 2.17 & Absent \\
\hline$F(G C F)=(G C F / Y, F I T O, D C P)$ & 2.18 & Absent & & 3.85 & Absent & 2.12 & Absent & 1.18 & Absent \\
\hline$F(D C P)=(D C P / Y, F I, T O, G C F)$ & 3.25 & Absent & & 1.88 & Absent & 2.28 & Absent & 4.58 & Absent \\
\hline Critical value & K & $1 \%$ & & & & & & & \\
\hline Pesaran et al. (2001) & 4 & 3.74 & 5.06 & & & & & & \\
\hline Narayan (2004) & 4 & 3.96 & 5.49 & & & & & & \\
\hline
\end{tabular}


Table 4 Long-run and short-run coefficients under ARDL

\begin{tabular}{|c|c|c|c|c|c|c|c|c|}
\hline & Country & & & & & & & \\
\hline \multicolumn{9}{|c|}{ Panel A: long-run estimation } \\
\hline \multirow{2}{*}{$\begin{array}{l}\text { Dependent variable Y: } \\
\text { Repressors }\end{array}$} & \multicolumn{2}{|l|}{ Bangladesh } & \multicolumn{2}{|l|}{ India } & \multicolumn{2}{|l|}{ Pakistan } & \multicolumn{2}{|l|}{ Sri Lanka } \\
\hline & Coefficient & t-stat & Coefficient & t-stat & Coefficient & t-stat & Coefficient & t-stat \\
\hline $\ln F \mid$ & $1.22^{\mathrm{a}}$ & 2.69 & $1.79^{\mathrm{a}}$ & 1.56 & $1.17^{\mathrm{a}}$ & 2.80 & $0.91^{\mathrm{a}}$ & 1.83 \\
\hline InTO & $0.43^{b}$ & 3.31 & $0.16^{\mathrm{a}}$ & 0.68 & $0.33^{\mathrm{a}}$ & 3.76 & $0.07^{\mathrm{b}}$ & 0.98 \\
\hline $\operatorname{lnGCF}$ & $0.16^{*}$ & 2.33 & $0.22^{\mathrm{b}}$ & -1.01 & $0.41^{*}$ & 1.96 & $0.14^{\mathrm{b}}$ & 4.22 \\
\hline $\operatorname{lnDCP}$ & $0.18^{\mathrm{a}}$ & 2.51 & $0.04^{b}$ & 0.47 & $0.15^{\mathrm{b}}$ & 1.45 & $0.47^{\mathrm{a}}$ & 1.65 \\
\hline C & $-3.09^{a}$ & -0.12 & -2.6 & -0.21 & -3.21 & -0.19 & 7.47 & 9.85 \\
\hline \multicolumn{9}{|c|}{ Panel B: Short-run estimation } \\
\hline $\mathrm{ECT}_{\mathrm{t}-1}$ & $-0.93^{b}$ & -8.43 & $-0.97^{a}$ & -5.39 & $-0.95^{\mathrm{a}}$ & -4.64 & $-0.75^{\mathrm{a}}$ & -5.98 \\
\hline$\Delta \mathrm{lnFl}$ & $0.22^{a}$ & 2.99 & $0.26^{\mathrm{b}}$ & 0.83 & $0.11^{\mathrm{b}}$ & 4.04 & $0.16^{\mathrm{a}}$ & 1.59 \\
\hline$\triangle \operatorname{lnTO}$ & $0.36^{b}$ & 3.91 & 0.09 & 0.66 & $0.36^{b}$ & 3.97 & $0.19^{b}$ & 1.14 \\
\hline$\triangle \operatorname{lnGCF}$ & $0.09^{b}$ & 2.84 & -0.16 & -3.86 & $0.09^{\mathrm{a}}$ & 1.72 & $0.08^{\mathrm{a}}$ & 3.79 \\
\hline$\triangle \mathrm{InDCP}$ & $0.16^{\mathrm{b}}$ & 2.91 & $0.04^{b}$ & 0.40 & -0.16 & -1.58 & $0.04^{a}$ & 1.76 \\
\hline \multicolumn{9}{|c|}{ Panel C. Residual Diagnostic Test } \\
\hline$R^{2}$ & 0.78 & & 0.89 & & 0.79 & & 0.72 & \\
\hline$\delta$ & 0.13 & & 0.28 & & 0.15 & & 0.45 & \\
\hline$F_{\text {statistics }}^{2}$ & $25.25^{\mathrm{a}}$ & & $4.51^{\mathrm{a}}$ & & $1.61^{\mathrm{a}}$ & & $4.15^{\mathrm{a}}$ & \\
\hline$x_{\text {Autocorrelation }}^{2}$ & $0.47[0.49]$ & & $0.97[0.85]$ & & $1.15[0.52]$ & & $0.89[0.25]$ & \\
\hline$x_{\text {Heteroskedasticity }}^{2}$ & $1.87[017]$ & & $1.15[0.37]$ & & $1.82[0.41]$ & & $2.14[0.47]$ & \\
\hline$x_{\text {Normality }}^{2}$ & $7.28[0.19]$ & & $6.94[0.29]$ & & $1.61[0.51]$ & & $1.89[0.18]$ & \\
\hline$x_{R E S E T}^{2}$ & $1.54[013]$ & & $1.26[0.29]$ & & $0.69[0.48]$ & & $0.81[0.38]$ & \\
\hline
\end{tabular}

Note $1 .{ }^{\mathrm{a}}{ }^{\mathrm{b}}$ indicates $1 \%$ and $5 \%$ level of significance, respectively

correlation, and the heteroscedasticity test showed the model to be free of the problem of heteroscedasticity. The Jarque-Bera normality test suggested the errors were normally distributed. The RESET test confirmed the model construction and f-statistics, ensuring model prediction and accuracy. Finally, the adjusted $R 2$ showed the model's ability to explain variance; $78,89,79$, and $72 \%$ of variance could be explained by the proposed model for Bangladesh, India, Pakistan, and Sri Lanka, respectively.

\section{Asymmetric estimation for the period 1975-2016}

Table 5 shows the nonlinear ARDL estimation (Shin et al. 2014) using Eq. (3) (see section "Methods"). We found that FI, TO, GCF, and DCP explained economic growth in Bangladesh by $86 \%$, India by $79 \%$, Pakistan by $89 \%$, and Sri Lanka by $83 \%$, and the remaining variation was explained by the error correction term. Also, the residual diagnostic test confirmed the model was free of serial correlation $\left(x_{\text {Autocorrelation }}^{2}\right)$, had no problem of heteroscedasticity $\left(x_{\text {Heteroskedasticity }}^{2}\right)$, and had normal residual distribution $\left(x_{\text {Normality }}^{2}\right)$. In addition, the Ramsay RESET test confirmed that the model's functional form was well established. The coefficient of Fpss indicated long-run cointergration f-statistics derived from the Wald test. We found that the f-statistic of each model was higher than the upper bound of the critical value at the $1 \%$ level of significance, extracted from the critical value proposed by Pesaran 
Table 5 Non-linear ARDL estimation results

\begin{tabular}{|c|c|c|c|c|c|c|c|c|}
\hline & \multicolumn{8}{|l|}{ Country } \\
\hline & \multicolumn{2}{|l|}{ Bangladesh } & \multicolumn{2}{|l|}{ India } & \multicolumn{2}{|l|}{ Pakistan } & \multicolumn{2}{|l|}{ Sri Lanka } \\
\hline & coefficients & t-stat & coefficients & t-stat & coefficients & t-stat & coefficients & t-stat \\
\hline \multicolumn{9}{|c|}{ Panel - A: Long-run Estimation } \\
\hline C & $-3.16^{a}$ & -1.41 & -26.65 & -2.39 & $18.52^{\mathrm{a}}$ & 1.33 & $-3.79^{\mathrm{a}}$ & -2.73 \\
\hline$Y(-1)$ & $-0.72^{\mathrm{a}}$ & -0.18 & -2.29 & -2.52 & $-0.76^{\mathrm{a}}$ & -3.58 & $-1.38^{\mathrm{a}}$ & -4.37 \\
\hline $\mathrm{FI} \_\mathrm{P}(-1)$ & $2.56^{\mathrm{b}}$ & 2.60 & $5.38^{\mathrm{b}}$ & -2.27 & $4.92^{\mathrm{a}}$ & 1.58 & $0.92^{\mathrm{a}}$ & 1.76 \\
\hline $\mathrm{FI} \_\mathrm{N}(-1)$ & $-4.07^{b}$ & -3.51 & $-7.11^{\mathrm{a}}$ & -1.96 & $-6.73^{\mathrm{a}}$ & -1.61 & $-0.18^{\mathrm{a}}$ & -1.41 \\
\hline $\mathrm{DCP}(-1)$ & $-8.09^{a}$ & -5.74 & 16.73 & 2.16 & $-7.98^{\mathrm{a}}$ & -2.57 & 1.43 & 0.97 \\
\hline $\operatorname{GCF}(-1)$ & $-4.52^{b}$ & -5.42 & -0.81 & -0.56 & -0.83 & -2.52 & -1.93 & -2.68 \\
\hline $\mathrm{TO}(-1)$ & $7.86^{\mathrm{a}}$ & 5.17 & -7.35 & -1.37 & $1.74^{\mathrm{a}}$ & 0.35 & 7.27 & 2.90 \\
\hline \multicolumn{9}{|c|}{ Panel - B: Short-run Estimation } \\
\hline$\Delta Y(-1)$ & $-0.53^{\mathrm{a}}$ & -1.78 & $1.95^{\mathrm{a}}$ & 3.39 & & & $0.78^{b}$ & 3.03 \\
\hline$\Delta Y(-2)$ & -0.35 & -1.63 & $1.55^{\mathrm{b}}$ & 3.58 & -0.65 & -2.68 & $1.20^{\mathrm{b}}$ & 3.94 \\
\hline$\Delta Y(-3)$ & $-0.55^{b}$ & -3.15 & $-0.22^{b}$ & -0.04 & $-0.61^{a}$ & -1.78 & & \\
\hline$\Delta Y(-4)$ & $-0.48^{\mathrm{a}}$ & 4.16 & $-0.14^{b}$ & -0.39 & $-0.77^{b}$ & -2.63 & $-0.51^{b}$ & -2.42 \\
\hline$\Delta \mathrm{FI} \_\mathrm{P}(-1)$ & $0.14^{\mathrm{a}}$ & 3.84 & $.03^{\mathrm{a}}$ & 1.93 & $0.78^{\mathrm{a}}$ & & $-2.10^{\mathrm{a}}$ & -4.29 \\
\hline$\Delta \mathrm{FI} \_\mathrm{P}(-2)$ & $0.39^{a}$ & 1.88 & $0.58^{\mathrm{a}}$ & 1.19 & $0.9^{b}$ & 1.60 & $-1.77^{\mathrm{b}}$ & -3.97 \\
\hline$\Delta \mathrm{FI} \_\mathrm{P}(-3)$ & $0.01^{a}$ & 0.87 & $1.74^{b}$ & 1.02 & $0.07^{b}$ & 0.91 & $-0.49^{b}$ & -1.67 \\
\hline$\Delta \mathrm{Fl} \_\mathrm{P}(-4)$ & $0.71^{\mathrm{a}}$ & 2.24 & $1.54^{b}$ & 2.44 & $0.04^{\mathrm{a}}$ & 2.19 & $-3.42^{\mathrm{a}}$ & -2.33 \\
\hline$\Delta \mathrm{FI} \_N(-1)$ & $0.07^{\mathrm{a}}$ & 1.54 & $-0.87^{b}$ & -1.89 & $-0.58^{\mathrm{a}}$ & -0.82 & $1.41^{\mathrm{b}}$ & 1.21 \\
\hline$\Delta \mathrm{FI} \_N(-2)$ & $-0.96^{\mathrm{a}}$ & -2.73 & $-0.65^{b}$ & -2.13 & $-1.78^{a}$ & -1.52 & $5.76^{\mathrm{b}}$ & 2.98 \\
\hline$\Delta \mathrm{FI} \_\mathrm{N}(-3)$ & $-1.04^{b}$ & -2.72 & $-0.67^{b}$ & -0.94 & $-0.33^{\mathrm{a}}$ & -0.92 & $1.14^{\mathrm{b}}$ & 1.08 \\
\hline$\Delta \mathrm{FI} \_N(-4)$ & $0.96^{\mathrm{a}}$ & 3.32 & $-1.12^{\mathrm{a}}$ & -1.42 & $-2.93^{\mathrm{a}}$ & -2.06 & -14.88 & -1.54 \\
\hline$\triangle \mathrm{DCP}(-1)$ & $6.66^{b}$ & 3.42 & & & $17.21^{*}$ & 2.81 & $-5.43^{b}$ & -3.57 \\
\hline$\triangle \mathrm{DCP}(-2)$ & $2.97^{b}$ & 1.98 & $-13.87^{b}$ & -2.22 & & & $-5.29^{b}$ & -3.86 \\
\hline$\triangle \mathrm{DCP}(-3)$ & & & & & $12.70^{a}$ & 2.59 & $-1.67^{b}$ & -1.37 \\
\hline$\triangle \mathrm{DCP}(-4)$ & $-6.29^{b}$ & -4.15 & $-1.21^{b}$ & -2.48 & $17.21^{*}$ & 2.81 & $-3.97^{b}$ & -2.53 \\
\hline$\Delta \mathrm{GCF}(-1)$ & $3.41^{\mathrm{b}}$ & 5.34 & & & & & $1.35^{b}$ & 2.62 \\
\hline$\Delta G C F(-2)$ & $1.46^{b}$ & 3.35 & & & $0.40^{b}$ & 1.36 & $0.22^{\mathrm{b}}$ & 0.68 \\
\hline$\triangle \mathrm{GCF}(-3)$ & $1.04^{b}$ & 4.38 & $0.16^{b}$ & 1.11 & $0.81^{\mathrm{a}}$ & 2.18 & $0.33^{\mathrm{a}}$ & 1.29 \\
\hline$\Delta \mathrm{GCF}(-4)$ & & & $0.57^{b}$ & 1.95 & 0.25 & 1.03 & $-1.45^{\mathrm{a}}$ & -0.17 \\
\hline$\Delta \mathrm{TO}(-1)$ & $-4.12^{b}$ & -4.57 & -4.48 & -1.13 & $8.96^{\mathrm{b}}$ & 2.28 & & \\
\hline$\Delta \mathrm{TO}(-2)$ & -2.61 & -2.96 & 17.21 & 1.72 & $11.74^{\mathrm{b}}$ & 3.72 & & \\
\hline$\Delta \mathrm{TO}(-3)$ & $-3.11^{b}$ & -3.89 & 3.70 & 0.77 & $2.95^{b}$ & 0.93 & & \\
\hline$\triangle \mathrm{TO}(-4)$ & $-3.46^{\mathrm{b}}$ & -4.45 & 10.99 & 2.12 & $14.03^{b}$ & 3.57 & & \\
\hline \multicolumn{9}{|c|}{ Panel - C: Symmetric Estimation } \\
\hline$F_{p s s}$ & 19.43 & & 15.79 & & 13.72 & & 9.15 & \\
\hline$L_{E X}^{+}$ & $3.47^{\mathrm{a}}$ & & $2.43^{\mathrm{a}}$ & & $6.47^{\mathrm{a}}$ & & $0.67^{\mathrm{a}}$ & \\
\hline$L_{E X}^{-}$ & $-5.65^{a}$ & & $-3.10^{\mathrm{a}}$ & & $10.50^{\mathrm{a}}$ & & $-0.13^{b}$ & \\
\hline$W_{L R}$ & $4.78(0.002)$ & & $1.33(0.003)$ & & $2.70(0.009)$ & & $1.17(0.001)$ & \\
\hline$W_{S R}$ & $12.17(0.004)$ & & $6.29(0.007)$ & & $6.18(0.004)$ & & $5.55(0.008)$ & \\
\hline
\end{tabular}


Table 5 Non-linear ARDL estimation results (Continued)

\begin{tabular}{|c|c|c|c|c|c|c|c|c|}
\hline & \multicolumn{8}{|l|}{ Country } \\
\hline & \multicolumn{2}{|l|}{ Bangladesh } & \multicolumn{2}{|l|}{ India } & \multicolumn{2}{|l|}{ Pakistan } & \multicolumn{2}{|l|}{ Sri Lanka } \\
\hline & coefficients & t-stat & coefficients & t-stat & coefficients & t-stat & coefficients & t-stat \\
\hline \multicolumn{9}{|c|}{ Panel - D: Residual Diagnostic and Model Stability Test } \\
\hline$R^{2}$ & 0.86 & & 0.79 & & 0.89 & & 0.83 & \\
\hline$\delta$ & 0.27 & & 0.32 & & 0.21 & & 0.44 & \\
\hline $\mathrm{F}_{\text {statistics }}^{2}$ & $10.42^{a}$ & & $5.28^{\mathrm{a}}$ & & $3.07^{\mathrm{a}}$ & & $3.73^{b}$ & \\
\hline$x_{\text {Autocorrelation }}^{2}$ & $2.20(0.18)$ & & $5.84(0.24)$ & & $4.84(0.45)$ & & $6.75(0.59)$ & \\
\hline $\mathrm{X}_{\text {Heteroskedasticity }}^{2}$ & $1.96(0.26)$ & & $1.40(0.49)$ & & $1.19(0.18)$ & & $1.49(0.18)$ & \\
\hline$x_{\text {Normality }}^{2}$ & $1.61(0.41)$ & & $1.51(0.77)$ & & $1.14(0.56)$ & & $1.64(0.43)$ & \\
\hline$x_{\text {RESET }}^{2}$ & $1.19(0.34)$ & & $0.97(0.23)$ & & $6.29(0.18)$ & & $3.29(0.18)$ & \\
\hline
\end{tabular}

Note 1 . The superscript " + " and "-- indicate positive and negative changes, respectively

Note 2. $F_{p s s}$ for F-statistics from Wald test for long-run cointegration

Note 3. $L_{F l}^{+}$and $L_{F l}^{-}$for long-run coefficients for financial innovation positive and negative changes

Note 4. $W_{L R}$ refers to the Wald test of long-run symmetryl

Note $5 . W_{S R}$ refers to the Wald test of the additive short-run symmetry condition

Note $6 .{ }^{\mathrm{a}}$ and ${ }^{\mathrm{b}}$ denote significance at the 1 and $5 \%$, levels, respectively

et al. (2001). This confirms the existence of long-run cointergration between FI, TO, GCF, and DCP and economic growth for the period Q1 1975 to Q4 2016. This finding is consistent with earlier ARDL tests (see Table 2).

Next, we investigated the existence of an asymmetric relationship between financial innovation and economic growth by applying the Wald test. In the Table 5 (panel C), WLR indicates the Wald test statistic for long-run symmetry, and WSR indicates the Wald test statistic for short-run symmetry. For the long run, the null hypothesis regarding the existence of a symmetric relationship was rejected at the $1 \%$ level of significance. Specifically, the Wald statistics were $(B D)=4.78(p=0.002)$ for Bangladesh, $W(B D)=1.33(p=0.003)$ for India, $W L R(B D)=2.70(p=0.009)$ for Pakistan, and WLR $(B D)=1.17(p=0.001)$ for Sri Lanka. It is evident that the associated $p$-values were less than $1 \%$. Thus, we can conclude the existence of an asymmetric relationship in the long run between the examined variables. For the short run, the null hypothesis was also rejected regarding symmetric relationships at the $1 \%$ level of significance. Specifically, the Wald statistics were $(B D)=12.17(p=0.006)$ for Bangladesh, $W$ $(I N D)=6.29(p=0.007$ for India $), W S R(P A K)=6.18 \quad(p=0.004)$ for Pakistan, and WSR $(S L)=5.55(p=0.008)$ for Sri Lanka. These findings suggest the existence of an asymmetric relationship between financial innovation and economic growth in Bangladesh, India, Pakistan, and Sri Lanka.

For the long-run estimations (see Table 5, panel A), we found that a positive shock in financial innovation was positively linked with economic growth in Bangladesh, India, Pakistan, and Sri Lanka while a negative shock was negatively linked with economic growth. This indicates that financial innovation in a financial system can stimulate economic growth. According to Chou (2007) and Chou and Chin (2011), financial innovation brings changes to a financial system that increase financial efficiency and increase saving propensity among the population by offering new and improved financial assets; this eventually aids capital formation and thus boosts economic growth. Mishra (2010), moreover, argued that financial innovation promotes the economic growth of emerging economies through welfare enhancement. For the short run (see Table 4, 
panel C), we found that a positive shock in financial innovation influenced economic growth in Bangladesh, India, and Pakistan but not Sri Lanka. Meanwhile, a negative shock in financial innovation produced mixed associations regarding economic growth in the sample countries.

\section{Granger causality test}

The existence of long-run cointegration was confirmed by ARDL and NARDL. This suggests the existence of at least one directional causality in the model-in the long run, the short run, or both. To ascertain directional causality between the set of variables, a Granger causality test was conducted under an error correction model (ECM). Table 6 shows the causality test results.

For long-run causality, the error correction term ECT $(-1)$ should be negative and statistically significant. Some ECTs $(-1)$ were negative and statistically significant at the $1 \%$ and $5 \%$ levels of significance. The findings confirmed the existence of long-run causality in the model. In particular, when economic growth $(\mathrm{Y})$ served as a dependent variable in the equation, the ECT coefficient was negative and significant. Thus, we can conclude that in the long run, economic growth can cause the adoption and diffusion of innovative financial products through the development of efficient financial institutions. This is in line with Bara and Mudxingiri (2016) Table 6.

As with long-run causality, in the short run, different directional causality was observed between the variable sets of each country. Table 7 shows the summary of short-run causality.

For Bangladesh. The study unveiled bidirectional causality between financial innovation and economic growth $[\mathrm{FI} \longleftrightarrow \mathrm{Y}]$ and financial innovation and gross capital formation [FI $\rightarrow \mathrm{GCF}]$. On the other hand, study also exposed unidirectional causality from economic growth to trade openness $[\mathrm{Y} \rightarrow]$, gross capital formation to economic growth $[\mathrm{GCF} \rightarrow \mathrm{Y}]$, domestic credit to private sector to economic growth $[\mathrm{DCP} \rightarrow \mathrm{Y}$, financial innovation to domestic credit to private sector [FI $\rightarrow \mathrm{DCP}]$, and trade openness to Gross capital formation [TO $\rightarrow \mathrm{GCF}$.

For India. Study divulged bidirectional causality between economic growth and financial innovation $[\mathrm{Y} \longrightarrow \mathrm{FI}]$. Furthermore, we observed unidirectional causality from trade openness to economic growth $[\mathrm{Y} \leftarrow \mathrm{TO}]$, economic growth to gross capital formation $[\mathrm{Y} \rightarrow \mathrm{GCF}$ ], financial innovation to trade openness [FI $\rightarrow \mathrm{TO}$ ], financial innovation to gross capital formation [FI $\rightarrow \mathrm{GCF}$ ], domestic credit to private sector to financial innovation $[\mathrm{FI} \leftarrow \mathrm{DCP}]$, and trade openness to domestic credit to private sector $[\mathrm{TO} \rightarrow \mathrm{DCP}]$.

For Pakistan study revealed directional causality between economic growth and financial innovation $[\mathrm{Y} \longleftrightarrow \longrightarrow \mathrm{FI}]$ and financial innovation and gross capital formation [FI $\longrightarrow \mathrm{GCF}]$. Study also exposed unidirectional causality from economic growth to trade openness $[\mathrm{Y} \rightarrow \mathrm{TO}$ ], gross capital formation to economic growth $[\mathrm{Y} \leftarrow \mathrm{GCF}$, trade openness to gross capital formation $[\mathrm{Y} \leftarrow \mathrm{GCF}]$, gross capital formation to domestic credit to private sector [FI $\longleftrightarrow \mathrm{GCF}$ ], trade openness to gross capital formation [TO $\rightarrow$ $\mathrm{GCF}$ ], and gross capital formation to domestic credit to private sector [GCF $\rightarrow \mathrm{DCP}$ ].

For Sri Lanka, the study uncovered bidirectional causality between economic growth and financial innovation $[\mathrm{Y} \longleftrightarrow \mathrm{FI}]$ and economic growth and gross capital formation 
Table 6 Granger-causality results

\begin{tabular}{|c|c|c|c|c|c|c|c|}
\hline & \multicolumn{5}{|c|}{ Short-run Causality } & \multicolumn{2}{|c|}{ Long-run causality } \\
\hline & $\Delta n Y_{t-1}$ & $\Delta n F I_{t-1}$ & $\Delta n T O_{t-1}$ & $\Delta n G C F_{t-1}$ & $\triangle n D C P_{t-1}$ & $\overline{\mathrm{ECT}}(-1)$ & Inference \\
\hline \multicolumn{8}{|l|}{ Bangladesh } \\
\hline$\Delta n Y_{t-1}$ & & $5.856^{* * *}$ & 4.047 & $7.742^{* *}$ & $6.988^{* *}$ & $-1.28^{* * *}$ & Long-run causality \\
\hline$\Delta n F I_{t-1}$ & $0.781^{* *}$ & & 2.482 & $1.441^{* *}$ & 4.114 & $-0.15^{* * *}$ & Long-run causality \\
\hline$\Delta n T O_{t-1}$ & $0.081^{* *}$ & 0.075 & & 1.03 & 0.315 & $-0.64^{* *}$ & Long-run causality \\
\hline$\Delta n G C F_{t-1}$ & 3.465 & $7.858^{* *}$ & $4.664^{*}$ & & 5.047 & 0.406 & \\
\hline$\triangle n D C P_{t-1}$ & 4.647 & $13.825^{* * *}$ & 2.393 & 1.369 & & 0.062 & \\
\hline \multicolumn{8}{|l|}{ India } \\
\hline$\Delta n Y_{t-1}$ & & $9.213^{* *}$ & $0.586^{* *}$ & 2.083 & 2.672 & $-0.58^{* *}$ & Long-run causality \\
\hline$\Delta n F I_{t-1}$ & $0.076^{* *}$ & & 2.542 & 0.571 & $2.47^{* *}$ & $-0.44^{* *}$ & Long-run causality \\
\hline$\Delta n T O_{t-1}$ & 2.624 & 2.759 & & $0.209^{* *}$ & 2.094 & 0.92 & \\
\hline$\Delta n G C F_{t-1}$ & $0.961^{* *}$ & $0.152^{* *}$ & 0.24 & & 2.388 & $-0.88^{* * *}$ & Long-run causality \\
\hline$\triangle n D C P_{t-1}$ & 1.194 & 3.188 & $7.55^{* *}$ & 5.611 & & -0.95 & \\
\hline \multicolumn{8}{|l|}{ Pakistan } \\
\hline$\Delta n Y_{t-1}$ & & $0.343^{* *}$ & 1.553 & $6.018^{* *}$ & 0.281 & $-0.13^{* * *}$ & Long-run causality \\
\hline$\Delta n F I_{t-1}$ & $4.892^{* *}$ & & 0.351 & $2.141^{* *}$ & 3.966 & $-0.84^{* *}$ & Long-run causality \\
\hline$\Delta n T O_{t-1}$ & $4.813^{* *}$ & 1.648 & & 6.163 & 4.078 & $-0.044^{* *}$ & Long-run causality \\
\hline$\Delta n G C F_{t-1}$ & 1.232 & $4.686^{* *}$ & $1.966^{* *}$ & & 4.028 & 0.095 & \\
\hline$\triangle n D C P_{t-1}$ & 1.253 & 4.522 & 11.838 & $9.383^{* *}$ & & 0.035 & \\
\hline \multicolumn{8}{|l|}{ Sri Lanka } \\
\hline$\Delta n Y_{t-1}$ & & $3.473^{* *}$ & 2.801 & $0.751^{* *}$ & 2.022 & $-0.48^{* *}$ & Long-run causality \\
\hline$\left.\Delta n F\right|_{t-1}$ & $2.917^{* *}$ & & $4.362^{* *}$ & 0.19 & 1.531 & $-0.36^{* *}$ & Long-run causality \\
\hline$\Delta n T O_{t-1}$ & 0.282 & 6.766 & & $4.992^{* *}$ & 2.468 & 0.43 & \\
\hline$\Delta n G C F_{t-1}$ & $5.286^{* *}$ & $6.297^{* *}$ & 5.843 & & 2.886 & $-0.99^{* *}$ & Long-run causality \\
\hline$\triangle n D C P_{t-1}$ & $4.419^{* *}$ & 2.62 & $1.705^{* *}$ & 2.016 & & 0.67 & \\
\hline
\end{tabular}

Note $1: * *, * *$, and $*$ indicates significant level at $1 \%, 5 \%$, and $10 \%$ respectively

[Y $\longrightarrow$ GCF]. Furthermore, study revealed unidirectional causality from economic growth to domestic credit to private sector $[\mathrm{Y} \rightarrow \mathrm{DCP}]$, trade openness to financial innovation $[\mathrm{FI} \leftarrow \mathrm{TO}$ ], financial innovation to gross capital formation [FI $\rightarrow \mathrm{GCF}$ ], gross capital formation to trade openness $[\mathrm{TO} \leftarrow \mathrm{GCF}$ ], and gross capital formation to domestic credit to private sector [GCF $\rightarrow$ DCP].

Table 7 Summary of Short-run causality

\begin{tabular}{|c|c|c|c|c|}
\hline Causality & Bangladesh & India & Pakistan & Sri Lanka \\
\hline Y VS FI & $\mathrm{Y} \longleftrightarrow \mathrm{FI}$ & $\mathrm{Y} \longleftrightarrow \mathrm{FI}$ & $\mathrm{Y} \longleftrightarrow \mathrm{Fl}$ & $\mathrm{Y} \longleftrightarrow \mathrm{FI}$ \\
\hline Y VS TO & $\mathrm{Y} \rightarrow \mathrm{TO}$ & $Y \leftarrow \mathrm{TO}$ & $\mathrm{Y} \rightarrow \mathrm{TO}$ & \\
\hline Y vs GCF & $\mathrm{Y} \leftarrow \mathrm{GCF}$ & $\mathrm{Y} \rightarrow \mathrm{GCF}$ & $\mathrm{Y} \leftarrow \mathrm{GCF}$ & $\mathrm{Y} \longleftrightarrow \mathrm{GCF}$ \\
\hline Y vs. DCP & $\mathrm{Y} \leftarrow \mathrm{DCP}$ & & & $\mathrm{Y} \rightarrow \mathrm{DCP}$ \\
\hline FI VS TO & & $\mathrm{FI} \rightarrow \mathrm{TO}$ & & $\mathrm{Fl} \leftarrow \mathrm{TO}$ \\
\hline FI vs GCF & $\mathrm{Fl} \longleftrightarrow \mathrm{GCF}$ & $\mathrm{Fl} \rightarrow \mathrm{GCF}$ & $\mathrm{Fl} \longleftrightarrow \mathrm{GCF}$ & $\mathrm{Fl} \rightarrow \mathrm{GCF}$ \\
\hline FI vs. DCP & $\mathrm{FI} \rightarrow \mathrm{DCP}$ & $\mathrm{FI} \leftarrow \mathrm{DCP}$ & & \\
\hline TO vs GCF & $\mathrm{TO} \rightarrow \mathrm{GCF}$ & $\mathrm{TO} \leftarrow \mathrm{GCF}$ & $\mathrm{TO} \rightarrow \mathrm{GCF}$ & $\mathrm{TO} \leftarrow \mathrm{GCF}$ \\
\hline TO vs. DCP & & $\mathrm{TO} \rightarrow \mathrm{DCP}$ & & \\
\hline GCF vs. DCP & & & $\mathrm{GCF} \rightarrow \mathrm{DCP}$ & $\mathrm{GCF} \rightarrow \mathrm{DCP}$ \\
\hline
\end{tabular}

Note: “ $\rightarrow$ " for unidirectional causality, " $\nleftarrow \rightarrow$ " for Bidirectional causality, and "-" for no causality 


\section{Conclusions and recommendations}

Efficient financial institutions not only optimize economic resources by channelizing across the country but also expedite economic development through efficient payment mechanisms and intermediation processes. Over the past decade, South Asian economies have experienced financial development with the emergence of improved and innovative financial assets and services via financial innovation. Merton (1992) characterized financial innovation as the engine driving financial systems toward improving the performance of real economies for sustainable development.

The present study investigated long-run cointegration between financial innovation and economic growth along with a set of macroeconomic variables for the period Q1 1975 to Q4 2016. To discover the long-run relationships between financial innovation and economic growth in Bangladesh, India, Pakistan, and Sri Lanka, we used the ARDL bounds testing approach proposed by Pesaran et al. (2001). We also estimated the existence of nonlinearity using the nonlinear ARDL approach proposed by Shin et al. (2014). The F-statistics in the ARDL bounds testing approach were higher than the upper bound of the critical value at the $1 \%$ level of significance, adopted from Pesaran et al. (2001). Thus, we can conclude that financial innovation stimulates economic growth in the long run. We also observed that the elasticities of financial innovation toward economic growth were positively influenced in both the short-run and long-run periods. These findings align with Mwinzi (2014), Qamruzzaman and Jianguo (2017), and Beck et al. (2014). Chou and Chin (2011) suggested that financial innovation increases the volume of financial product variety along with efficient financial services, eventually promoting financial-development-led economic growth. This implies that financial innovation is positively linked with economic growth. Furthermore, Moyo et al. (2014) argued that financial innovation is the ultimate result of financial reform, promoting financial efficiency in the financial system and leading to sustainable economic growth.

The NARDL findings also support the existence of long-run relationships. They also reject the null hypothesis regarding the nonexistence of an asymmetric relationship between financial innovation and economic growth, both in the short run and the long run. Thus, we can infer an asymmetric relationship between financial innovation and economic growth. In addition, we observed positive changes in financial innovation positively linked in both the long run and short run. These findings suggest that any improvement in financial innovation can bring about positive changes in the economy. However, negative changes in financial innovation were adversely linked with economic growth. Yet, the elasticities toward economic growth were minimal and statistically insignificant for the short run. In the long run, however, the effect was statistically significant at the $1 \%$ and $5 \%$ levels.

Arnaboldi and Rossignoli (2013) argued that financial innovation is a double-edged sword that can promote sustainable economic growth through developing the financial sector while also having a dark side (Beck et al. 2016). However, the negative effect of financial innovation on economic growth is still low and scarcely identified in empirical studies.

To establish directional causality, we used the Granger causality test under an error correction model. Bidirectional causality was found between financial innovation and economic growth in Bangladesh, India, Pakistan, and Sri Lanka for the period Q1 1975 
to Q4 2016. This finding supports the feedback hypothesis between financial innovation and economic growth in the long run. This finding aligns with Ajide (2015). For short-run causality, we observed bidirectional causality between financial innovation and economic growth in Bangladesh, India, Pakistan, and Sri Lanka. This supports the feedback hypothesis for the short run as well. Thus, we can assume that growth in Bangladesh, India, Pakistan, and Sri Lanka can be caused by the evolution and adoption of financial innovation in the financial system.

In particular, financial innovation can influence economic growth by providing an efficient financial system along with financial diversification. Meanwhile, economic growth puts pressure on the financial system to create innovative financial assets and services to mitigate the demand for financial services. The positive link between financial innovation and economic growth suggests that Bangladesh, India, Pakistan, and Sri Lanka should encourage financial innovation in their financial systems. Their financial sectors should develop financial institutions that can introduce innovative financial products and services that will diffuse throughout the economy. Thus, their governments should formulate financial policies to promote financial innovation, development, and inclusion while minimizing risk levels to ensure stability in the financial sector.

Accordingly, bank-based and market-based financial development needs to proceed effectively and efficiently to obtain the maximum benefits from financial innovation. As such, the governments of Bangladesh, India, Pakistan, and Sri Lanka should pay particular attention to infrastructural development, financial transparency, technological advancement, and regional cooperation in financial reforms.

\section{Abbreviations \\ ADF: For Augmented Dickey-Fuller; ARDL: Autoregressive Distributed Lagged; DCP: Domestic Credit to Private Sector; FI: Financial Innovation; GCF: Gross Capital Formation; KPSS: Kwiatkowski-Phillips-Schmidt-Shin; NARDL: Nonlinear Autoregressive Distributed Lagged; P-P: Phillips-Perron; TO: Trade Openness,}

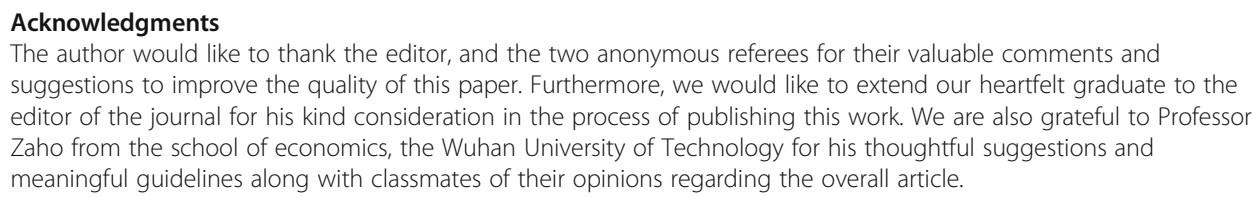

Availability of data and materials

Upon request in future, we, at this moment, confirming that all the pertinent information will be disclosed for further use.

\section{Authors' contributions}

The concept and design of this article come from Professor WJ and after that data collection, empirical study review of conceptual development and drafting done by Md. Q and finally critical review and import intellectual content assessment is done by Professor Wei Jianguo and effort by authors in the article, the ration of contribution equally likely. Both authors read and approved the final manuscript.

Competing interests

The authors declare that they have no competing interests. 


\section{Consent for publication}

As par study concern, is purely based on secondary data which is publically available and there is not such private and exclusive information for that need to get approval for publically publication.

\section{Publisher's Note}

Springer Nature remains neutral with regard to jurisdictional claims in published maps and institutional affiliations.

\section{Received: 19 December 2017 Accepted: 15 August 2018}

Published online: 06 September 2018

\section{References}

Adu-Asare Idun A, Q.Q. Aboagye A (2014) Bank competition, financial innovations and economic growth in Ghana. Afr J Econ Manage Stud 5:30-51

Aghion P and Howitt P. (1990) A model of growth through creative destruction. National Bureau of Economic Research Ahmad E, Malik A (2009) Financial sector development and economic growth: an empirical analysis of developing countries. J Econ Cooperation Dev 30:17-40

Ahmed AD (2006) The impact of financial liberalization policies: the case of Botswana. J Afr Dev 1:13-38

Ajide FM (2015) Financial innovation and sustainable development in selected countries in West Africa. Innov in Finance 15:85-112

Ang JB (2008) What are the mechanisms linking financial development and economic growth in Malaysia? Econ Model 15:38-53

Ansong A, Marfo-Yiadom E, Ekow-Asmah E (2011) The effects of financial innovation on financial savings: evidence from an economy in transition. J Afr Bus 12:93-113

Arestis P, Demetriades P (1997) Financial development and economic growth: assessing the evidence. Econ J 5:783-799

Arnaboldi F, Rossignoli B (2013) Financial innovation in banking. University of Milan, Milan, pp 1-30

Asian Development Bank. (2017) South Asian Economy

Bahmani-Oskooee M, Economidou C, Gobinda Goswami G (2005) How sensitive are Britain's inpayments and outpayments to the value of the British pound. J Econ Stud 32:455-467

Bahmani-Oskooee M, Mohammadian A (2016) Asymmetry effects of exchange rate changes on domestic production: evidence from nonlinear ARDL approach. Aust Econ Pap 55:181-191

Bara A, Mudxingiri C (2016) Financial innovation and economic growth: evidence from Zimbabwe. Invest Manage Finan Innov 13:65-75

Bara A, Mugano G, Roux PL (2016) Financial innovation and economic growth in the SADC. Econ Res Southern Africa 1:1-23 Barro R (1991) Economic growth in a cross section of countries. Q J Econ 106:407-443

Beck T. (2010) Financial Development and Economic Growth: Stock Markets versus Banks? Africa's Financial Markets: A Real Development Tool. Tilburg University, 3

Beck T, Chen T, Lin C et al (2016) Financial innovation: the bright and the dark sides. J Bank Financ 72:28-51

Beck T, Levine R (2004) Stock markets, banks, and growth: panel evidence. J Bank Financ 28:423-442

Beck T, Senbet L, Simbanegavi W (2014) Financial inclusion and innovation in Africa: an overview. J Afr Econ 24:i3-i11

Blair MM (2011) Financial innovation, leverage, bubbles and the distribution of income. Rev Bank Finance Law 30:225-311

Bourne C, Attzs M (2010) The role of economic institutions in Caribbean economic growth and development: from Lewis to the present. Q J Econ 15:1-28

Chou YK (2007) Modelling financial innovation and economic growth. J Bus Manage 2:1-36

Chou YK, Chin MS (2011) Financial innovations and endogenous growth. J Econ Manage 25:25-40

Delatte A-L, López-Villavicencio A (2012) Asymmetric exchange rate pass-through: evidence from major countries. J Macroecon 34:833-844

Demetriades PO and Andrianova S. (2005) Sources and effectiveness of financial development: what we know and what we need to know. Research Paper, UNU-WIDER, United Nations University (UNU)

Demetriades PO, Luintel KB (1996) Financial development, economic growth and banking sector controls: evidence from India. Econ J 106:359-374

Dickey DA, Fuller WA (1979) Distribution of the estimators for autoregressive time series with a unit root. J Am Stat Assoc 74: $427-431$

Dosi G, Fagiolo G, Roventini A (2010) Schumpeter meeting Keynes: a policy-friendly model of endogenous growth and business cycles. J Econ Dyn Control 34:1748-1767

Engle R, Granger C (1987) Cointegration and error correction representation: estimation and testing. Econometrica, p 55

EViews9.5. (2017)

Ghali KH, Ahmed A-M (1999) The intertemporal causal dynamics between fixed capital formation and economic growth in the group-of-seven countries. Int Econ J 13:31-37

Goldsmith RW (1969) Financial Structure and Development. Yale Univ. Press, New Haven CN

Greenwood J, Jovanovic B (1990) Financial development, growth, and the distribution of income. J Polit Econ 98:1076-1107

Gregorio DJ, Guidotti PE (1995) Financial development and economic growth. World Dev 23:433-448

Gurley J, Shaw E (1955) Financial aspects of economic development. Am Econ Rev 45:516-537

Howitt P (2000) Endogenous growth and cross-country income differences. Am Econ Rev:829-846

Ihan O (2008) Financial development and economic growth: evidence from Turkey. Appl Econ Int Dev 8:85-98

Johansen S (1991) Estimation and hypothesis testing of Cointegration vectors in Gaussian vector autoregressive models. Econometrica 59:1551-1580

Johansen S (1995) Likelihood-based inference in Cointegrated vector autoregressive models. Oxford University Press, Oxford Johansen S (1998) Statistical analysis of co integration vectors. J Econ Dyn Control 10:231-254

Johansen S, Juselius K (1990) Maximum likelihood estimation and inference on Cointegration - with applications to the demand for money. Oxf Bull Econ Stat 51:169-210 
Jung WS (1986) Financial development and economic growth: international evidence. Econ Dev Cult Chang 34:333-346 Khan MA, Qayyum A, Sheikh SA, Siddique O (2005) Financial development and economic growth: the case of Pakistan. Pakistan Dev Rev 12:819-837

King RG, Levine R (1993a) Finance and growth: Schumpeter might be right. Q J Econ 108:717-737

King RG, Levine R (1993b) Finance entrepreneurship, and growth: theory and evidence. J Monet Econ 32:513-542 Knell M (2015) Schumpeter, Minsky and the financial instability hypothesis. J Evol Econ 25:293-310

Kotsemir M, Abroskin A, Meissner D (2013) Innovation concept and typology-an evolutionary Discussion. Sci, Technol Innov 50 Kwiatkowski D, Phillips P, Schmidt P et al (1992) Testing the null hypothesis of stationarity against the alternative of a unit root: how sure are we that economic time series have a unit root? J Econ 54:159-178

Laeven L, Levine R, Michalopoulos S (2015) Financial innovation and endogenous growth. J Financ Intermed 24, 24(1)

Levine R (1997) Financial development and economic growth: views and agenda. J Econ Lit 35:688-726

Levine R, Renelt D (1992) A sensitivity analysis of cross-country growth regressions. Am Econ Rev:942-963

Lumpkin S (2010) Regulatory issues related to financial innovation. OECD Journal: Financial Market Trends (2):1-31

Mannah-Blankson T, Belnye F (2004) Financial innovation and the demand for money in Ghana. Bank of Ghana, Accra, pp 1-23

Merton RC (1992) Financial innovation and economic performance. J Appl Corp Finance 4:12-24

Michael N, Ojiegbe U,L, Peter O (2015) Bank and non-Bank financial institutions and the development of the Nigerian economy. Int J Innov Educ Res 10:23-36

Michalopoulos S, Laeven L and Levine R. (2009) Financial innovation and endogenous growth. National Bureau of Economic Research

Michalopoulos S, Laeven L, Levine R (2011) Inancial innovation and endogenous growth. National Bureau of Economic Research, USA, pp 1-33

Miller MH (1986) Financial innovation: the last twenty years and the next. J Finance Quan Anal 10:12-22

Ministry of Finance (2016) Bangaledshe economic review 2016. In: Government of the People's Republic of Bangladesh

Mishra PK (2010) Financial innovation and economic growth -a theoretical approach. J Appl Corp Finance 15:1-6

Moyo J, Nandwa B, Council DE et al (2014) Financial sector reforms, competition and banking system stability in sub-Saharan Africa. In: New perspectives

Mwinzi DM (2014) The effect of Finanical innovation on economic growth in Kenya. School of Business. University of Nairobi, Kenya, p 54

Napier M (2014) Real money, new Frontiers: case studies of financial innovation in Africa. Financial Innova Stud 10:1-10

Narayan PK (2004) Reformulating critical values for the bounds F-statistics approach to Cointegration: an application to the tourism demand model for Fiji. Monash University, Australia, pp 1-40

Narayan S, Narayan PK (2005) An empirical analysis of Fiji's import demand function. J Econ Stud 32:158-168

Ndlovu G (2013) Financial sector development and economic growth: evidence from Zimbabwe. Int J Econ Financ Issues 3:435-446

Patrick HT (1966) Financial development and economic growth in underdeveloped countries. Econ Dev Cult Chang 14:174-189

Paul BP (2014) Testing export-led growth in Bangladesh: an ARDL bounds test approach. Int J Trade, Econ Finance:1-5

Pesaran HH, Shin Y (1998) Generalized impulse response analysis in linear multivariate models. Econ Lett 58:17-29

Pesaran MH, Shin Y, Smith RJ (2001) Bounds testing approaches to the analysis of level relationships. J Appl Econ 16:289-326

Phillips K, Wrase J and Mall TI. (1999) Schumpeterian growth and endogenous business cycles. Federal Reserve Bank of Philadelphia

Phillips PCB, Perron P (1988) Testing for a unit root in time series regression. Biometrika 75:335-346

Qamruzzaman M, Jianguo W (2017) Financial innovation and economic growth in Bangladesh. Financ Innov 3:19

Rahman MH (2004) Financial development -economic growth Nexus:a case study of Bangladesh. Bangladesh Dev Stud 3:113-127

Saad W (2014) Financial development and economic growth: evidence from Lebanon. Int J Econ Financ 6:173-184

Saqib N (2015) Review of literature on finance-growth Nexus. J Appl Finance Bank 5:175-195

Schumpeter (1911) The theory of economic development. Harvard University Press, Cambridge

Schumpeter J. (1912) Theorie der Wirtschaftlichen Entwicklung. The Strategy Design

Schumpeter JA (1982) The theory of economic development: an inquiry into profits, capital, credit, interest, and the business cycle (1912/1934). Transaction Publishers-1982-January 1:244

Sekhar GVS (2013) Theorems and theories of financial innovation: models and mechanism perspective. Financ Quanti Anal 1:26

Shahbaz M, Mallick H, Mahalik MK et al (2016) The role of globalization on the recent evolution of energy demand in India: implications for sustainable development. Energy Econ 55:52-68

Shin Y, YU B, Greenwood-Nimmo M (2014) Modelling asymmetric cointegration and dynamic multipliers in a nonlinear ARDL framework. In: Festschrift in Honor of Peter Schmidt. Springer, pp 281-314

Shittu Al (2012) Financial intermediation and economic growth in Nigeria. British Journal of Arts and Social Sciences 4:164-179

Silve F, Plekhanov A (2014) Institutions, innovation and growth: cross-country evidence, vol 28. European Bank for Reconstruction and Development, London

Solow RM (1957) Technical change and the aggregate production function. Rev Econ Stat:312-320

Sood V, Ranjan P (2015) Financial innovation in India: an empirical study. J Econ Bus Rev 10:1-20

Tufano P (2003) Financ Innov 1:307-335

Verheyen F (2013) Interest rate pass-through in the EMU-new evidence using the nonlinear ARDL framework. Econ Bull 33: 729-739

Wachter JA (2006) Comment on: "can financial innovation help to explain the reduced volatility of economic activity?". J Monet Econ 53:151-154

Wadud M (2009) Financial development and economic growth: a cointegration and errorcorrection modeling approach for south Asian countries. Econ Bull 29:1670-1677

Were M, Nzomoi J, Rutto N (2012) Assessing the impact of private sector credit on economic performance: evidence from sectoral panel data for Kenya. Int J Econ Financ 4:182

World Bank. (2017) World Development Indicators. Available at: http://data.worldbank.org/data-catalog/world-development-indicators World Economic Outlook. (2017) World Economic Outlook (WEO) data, IMF 